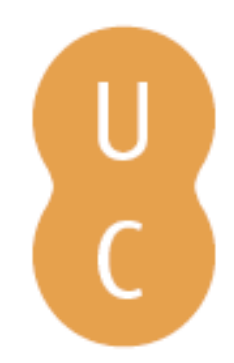

\title{
pompalina
}

\section{Effects of Eucalyptus globulus plantations in low order streams of central Portugal}

Autor(es): $\quad$ Canhoto, Cristina; Abelho, Manuela; Graça, Manuel Augusto

Publicado por: Imprensa da Universidade de Coimbra

URL

persistente: URI:http://hdl.handle.net/10316.2/32727

DOI: $\quad$ DOI:http://dx.doi.org/10.14195/978-989-26-0336-0_33

Accessed : $\quad$ 26-Apr-2023 12:20:22

A navegação consulta e descarregamento dos títulos inseridos nas Bibliotecas Digitais UC Digitalis, UC Pombalina e UC Impactum, pressupõem a aceitação plena e sem reservas dos Termos e Condições de Uso destas Bibliotecas Digitais, disponíveis em https://digitalis.uc.pt/pt-pt/termos.

Conforme exposto nos referidos Termos e Condições de Uso, o descarregamento de títulos de acesso restrito requer uma licença válida de autorização devendo o utilizador aceder ao(s) documento(s) a partir de um endereço de IP da instituição detentora da supramencionada licença.

Ao utilizador é apenas permitido o descarregamento para uso pessoal, pelo que o emprego do(s) título(s) descarregado(s) para outro fim, designadamente comercial, carece de autorização do respetivo autor ou editor da obra.

Na medida em que todas as obras da UC Digitalis se encontram protegidas pelo Código do Direito de Autor e Direitos Conexos e demais legislação aplicável, toda a cópia, parcial ou total, deste documento, nos casos em que é legalmente admitida, deverá conter ou fazer-se acompanhar por este aviso. 
MIGUEL ÂNGELO PARDAL JOÄO CARLOS MARQUES MANUEL AUGUSTO GRAÇA Scientific Editors

\section{Aquatic Ecology of the Mondego River Basin Global Importance of Local Experience}




\author{
MIGUEL ÂNGELO PARDAL \\ JOẢO CARLOS MARQUES \\ MANUEL AUGUSTO GRAÇA \\ Scientific Editors
}

\title{
Aquatic Ecology of the Mondego River Basin Global Importance of Local Experience
}




COORDENAÇÃO EDITORIAL
Imprensa da Universidade de Coimbra
CONCEPÇÃO GRAFICA
António Barros
INFOGRAFIA
António Resende
Estimulus [design] • Coimbra
EXECUÇÃO GRAFICA
GRAFIASA
ILUSTRAÇÃO DA CAPA
P. P. Cunha e ]. Dinis
ISBN
972-8704-04-6
DEPOSITO LEGAL
I75038/02

(C) JANEIRO 2002, IMPRENSA DA UnIVERSIDADE DE COIMBRA

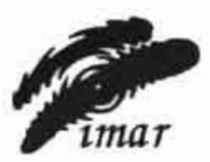

CPIMAR

imar

OBRA PUBLICADA COM O PATROCINIO DE:

IMAR - INSTITUTO DO MAR

IPIMAR - INSTITUTO DE INVESTIGAÇĀO DAS PESCAS E DO MAR 



\author{
CRISTINA Canhoto ' \\ MANUela ABelHo ' \\ Manuel Augusto Graça '
}

\title{
EFFECTS OF Eucalyptus globulus PLANTATIONS IN LOW ORDER STREAMS OF CENTRAL PORTUGAL
}

\begin{abstract}
Low order streams derive most of their energy from the riparian vegetation. Therefore, changes in forest cover have the potential to affect stream biota. Herein we assess the effects of Eucalyptus globulus afforestation to low order streams by comparing (a) the structure of macroinvertebrate communities between impacted (eucalyptus plantations) and unimpacted (deciduous forest) streams; (b) decomposition rates of eucalyptus leaves and some native species; (c) fungal colonisation and (d) sporulation of decomposing leaves. During autumn/winter, streams flowing through eucalyptus forests contained a lower number of invertebrates and taxa than streams running through deciduous forests. The low number of invertebrate taxa and individuals might be a consequence of hydrology and/or low quality food resource of leaves. Decomposition of leaves and fungal sporulation followed a same pattern: leaves of alder decomposed at a fast rate. followed by chestnut, eucalyptus and oak. The colonisation of eucalyptus leaves by aquatic hyphomycetes was highly limited by the curicle (and facilitated by stomata). It progressed predominantly in and from the eucalyptus leaf mesophyll to the outside. Eucalyptus oils and, to a lesser extend, polyphenols. were strong deterrents to fungal growth. A possible incorporation of eucalyptus litter into secondary production in a reasonable time span is suggested. We hypothesise that aquatic hyphomycetes play a dominant role in the eucalyptus breakdown process overlapping shredder low consumption or low density.
\end{abstract}

\section{Introduction}

The exotic species Eucalyptus giobulus (Labill.) was introduced in 1829 in the Iberian Peninsula. Nowadays, this species is common and widespread in Portugal where monocultures occupy over $21 \%$ of the forested area. The evergreen eucalyptus was mainly planted for the paper mill industry replacing the original mixed deciduous forest

17. IMAR - Insututo do Mar, Centro Interdisciplinar de Coimbra a/c Departamento de Zoologia, Universidade de Cormbra. 3004-517 Combra, Portugal 
and pine plantations. Given the large evidence that low order streams derive most of their energetic requirements from senescent leaves originated in the riparian zone and that leaves of trees differ in their quality, changes in the riparian forest have the potential to affect the streams. Alterations of forest cover or litter input were already documented to affect the aquatic biota (Molles 1982, Stout et al. 1993. Wallace et al. 1999).

Attempts to document the effects of eucalyptus afforestation on the energetics of Portuguese low order streams are few and recent (e.g., Abelho and Graça 1996. Canhoto and Graça 1999). However, changes in the structure and functioning of these ecosystems were, nevertheless, expected.

In order to determine the ecological effects of eucalyptus plantations on Central Portuguese streams we compared the macroinvertebrate community structure of low order streams flowing through three forest types - deciduous, eucalyptus and mixed (eucalyptus with a deciduous riparian vegetation). Moreover, because the physicochemical characteristics of leaves affect decomposition through their influence on fungal colonisation and invertebrate consumption. we also analysed fungal richness and sporulation rates of fungi colonising decomposing leaves. Finally, we examine mechanisms of fungal invasion of leaves and tested the potential effect of polyphenolics and eucalyptus oils to inhibit fungal growth.

This Chapter includes information already published in Hydrobiology (1996. 324: 195-204, 1996. 333: 79-85) and Microbial Ecology (1999, 37: 163-172).

\section{Materials and methods}

Macroinvertebrate community structure

The first question to address was if the invertebrate community differed between perturbed and unperturbed streams. We selected streams running through the forest types classified according to the surrounding vegetation into "deciduous" (dominated by Costonea satrva and to a lower extent Quercus spp.), "eucalyptus" (in E globulus forests) and "mixed" (flowing through eucalyptus forest but bordered by indigenous deciduous trees: Salix spp., Quercus spp., and others). We collected samples of macroinvertebrates in three deciduous (DI,D2,D3), three eucalyptus ( $E$ I, E2, E3) and four mixed forest (MI, M2. M3, M4) streams. The deciduous forest streams were located at Mata da Margaraça and Fraga da Pena. They were compared with streams at Serra do Caramulo. Some of which run to the Mondego basin whereas other run to the Vouga basin. Six sample replicates were collected from each site with a hand net $(0.3 \times 0.3 \mathrm{~m} ; 0.5 \mathrm{~mm}$ mesh size, covering an area of $0.3 \times$ Im). The samples were transported to laboratory to be sorted. Animals were kept in $70 \%$ alcohol and identified to the lowest possible taxonomic level. For each sample, the number of individuals and taxa were calculated. Comparisons among three stream types in terms of number of taxa and number of individuals were made by ANOVA. 


\section{Decomposition rates}

Leaves of alder (Alnus glutinosa), chestnut (Costanea sativa), oak (Quercus faginea) and eucalyptus (E globulus) were collected during senescence from individual trees, and stored dry until needed. They were dried (50"C; $48 \mathrm{~h})$, weighed and assembled in groups of $3 \mathrm{~g}$ in nylon bags ( $0.5 \mathrm{~mm}$ mesh size). A total of 160 packs tied to 10 ropes (4 replicates of each species per rope) were placed in Ribeira do Sobral Cid. Coimbra. At days $0,3,7,14,21,28,42,56,70$ and 84 , one rope was randomly retrieved from the stream. The leaves from the bags were then washed. incubated for sporulation (see below), and dried at 50 " $\mathrm{C}$ for $48 \mathrm{~h}$. Weight loss was expressed as a percentage of initial weight $(n=3)$. Decomposition rates were estimated using the exponential decay model $W_{1}=W_{0} e^{i s}$, where $W_{1}$ is the remaining weight at time $t_{1} W_{0}$ is the initial weight and $k$ is the decay coefficient (Petersen and Cummins 1974). Regression lines (In transformed data) were compared by Covariance Analysis followed by a Tukey test (Zar 1984).

Before drying the leaves, leaf fragments were individually incubated in petri dishes flooded with sterile water for 2 days $\left(15^{\circ} \mathrm{C}\right)$. This time was enough to get abundant detached conidia. Identification of fungal conidia was made under an inverted microscope.

Fungal colonisation: invasion processes and growth limications

In a second decomposition experiment. changes in leaves nitrogen content (Kjeldahl method: Wilde et al. 1972) and total phenolics (Folin Denis assay; Martin and Martin 1982) were analysed. Eucalyptus leaf fragments were also prepared for observations at light and electron microscopy. To observe cuticle changes and fungal invasive processes small eucalyptus leaf sections were fixed in $2.5 \%$ glutaraldehyde, post-fixed in $1 \%$ buffered osmium tetroxide and dehydrated in graded ethanol series (20-100\%). SEM observations were made on small leaf sections critical-point dried with carbon dioxide as transition fluid, coated with gold and mounted on aluminium stubs. For optical microscopy, the samples were dehydrated and embedded in Spurr's resin (Spurr 1969). Semithin sections were than stained with $0.2 \%$ toluidine blue before observation.

To test the effects of eucalyptus secondary compounds on fungal growth, increasing concentrations (0-7.5\%) of tannic acid or eucalyptus essential oils were added to a malt extract agar medium. Laboratory cultures of aquatic hyphomycetes involved in leaf decomposition were used to inoculate the agar plates (at least 3 replicates per treatment). We used the following species: Articulosporo tetracladia. Heliscus lugdunensis, Lemonniera oquatica. Lunulospora curvula. Tricladium angulatum and Tricladium groule. Fungal growth was allowed for 15 days and expressed as the increase in the colony size (squared mean diameter $-\mathrm{cm}^{2}$ ). Results were treated using one-way ANOVA followed by a Student-Newman-Keuls test. The EC50 values were obtained using a Probit analysis (Finney 1971). 


\section{Results}

In terms of quantity of invertebrates, the number of individuals was significantly higher in the deciduous forest streams than in the eucalyptus or mixed forest streams $(H=5.94, P<0.05)$. In terms of taxa, higher richness was observed in the deciduous forest streams (Fig, I) but the difference was just above the significative limit $(H=5.66$, $P>0.05$ ). The proportion of individuals per functional group was similar in all streams with predominance of collectors and shredders.

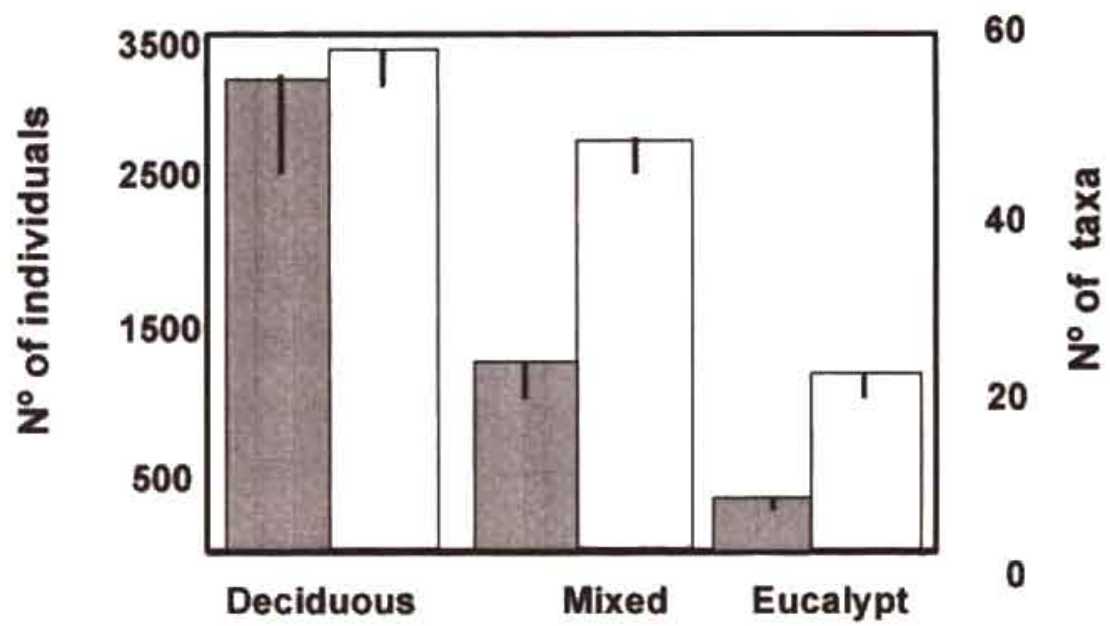

Fig 1. Number of individuals (dark bars) and number of taxa (light bars) of invertebrates (mean \pm SE) collected in the streams flowing through deciduous, mixed and eucalyptus forests (after Abelho and Graca 1996)

Leaves of the four tested species differed in their breakdown rates (ANCOVA; $P<$ $0.05)$. Processing was faster on $A$. glutinosa $\left(K-0.016\right.$ day $\left.{ }^{\prime}\right)$ followed by $C$ sativa $(K-$ 5080.008 day'). E globulus $(K-0.007$ day') and, finally, $Q$. fogineo ( $K-0.004$ day') (Fig. 2a). Initial nitrogen $(\mathrm{N})$, expressed as a \% of leaf dry weight, ranged from $0.78 \%$ (chestnut) to $2.8 \%$ (aider). Oak and eucalyptus presented intermediate values (1.3\% and $1.5 \%$, respectively). Following immersion of leaves in the streams, $\mathrm{N}$ contents increased with conditioning time in all leaf species to a maximum at 21 days in alder and over 60 days for the other species. Higher initial polyphenolic percentages were observed in leaves of oak (14.1\%) followed by chestnut (9.2\%), eucalyptus $(6.1 \%)$ and alder (5\%) (Fig. 2b). Soon after immersion, the leaves polyphenolic contents decreased rapidly and, by day 28 , it stabilised in about $2 \%$. 
(a)

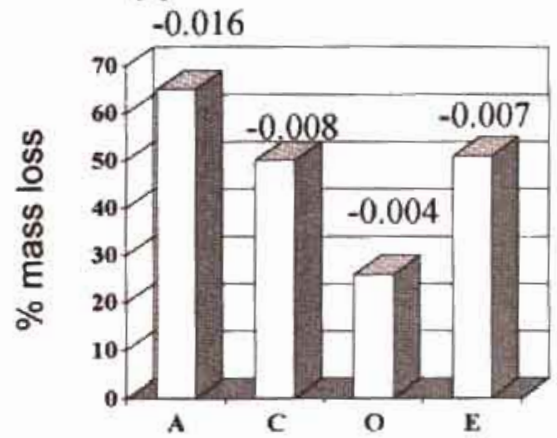

(b)

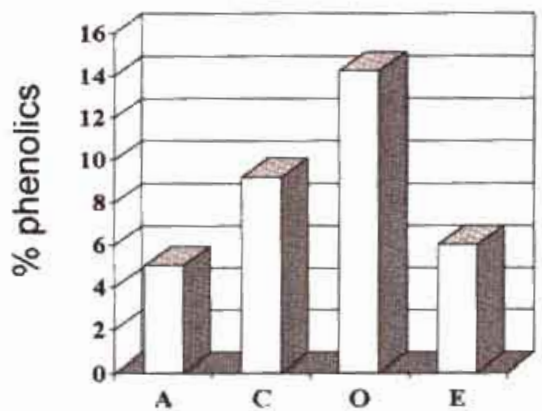

Fig. 2. (a) Percentage of mass loss and $k$ values of leaves of alder (A), chestnut (C), oak $(O)$ and eucalyptus (E) decomposing, over 84 days, in a stream: (b) Intral phenolic content each leaf type (after Canhoto and Graça 1996).

Conidial production of fungi colonising decomposing leaves followed the same pattern as breakdown rates being quicker on the faster processed leaves of $A$. glutinosa and $C$. sativa than in the $E$ globulus and $Q$. foginea. However, a clear increase in the number of fungal species occurred with time for all leaf species (Fig. 3).

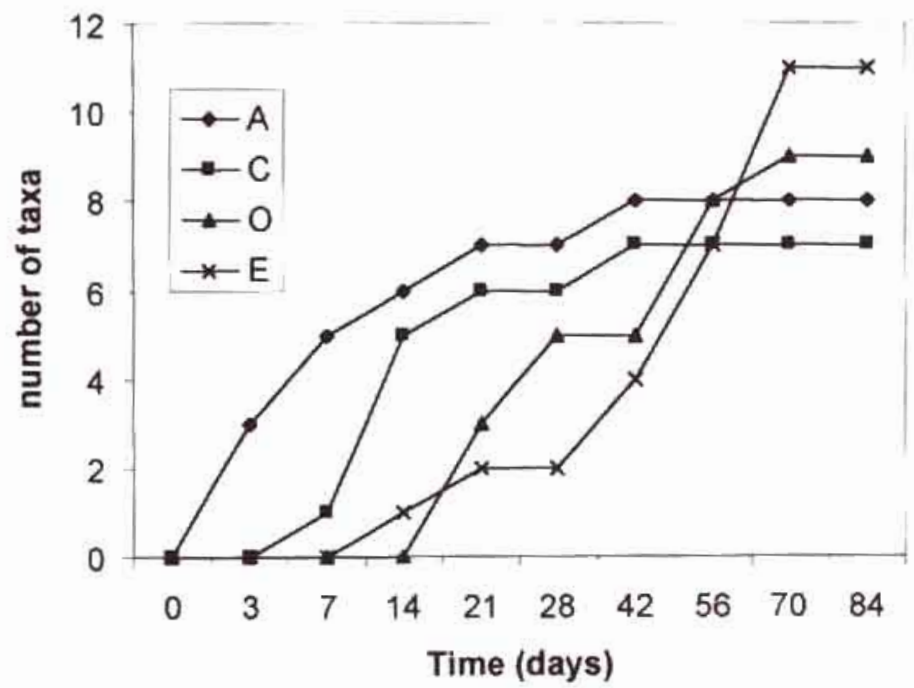

Fig. 3. Cumulative number of taxa of aquatic hyphomycetes in decomposing alder, chestnut, oak and eucalyptus leaves over $B 4$ days $A=$ alder: $C=$ chestnut: $O=$ oak; $E=$ eucalyptus.

Transverse sections of eucalyptus leaves showed a coherent and resistant waxy cuticle over the epidermis with thinner extensions lining the substomatal cavities. This barrier was practically unaltered through 5 weeks of immersion isolating the leaf parenchyma from the exterior. Mycelial penetration, apparent soon after immersion, 


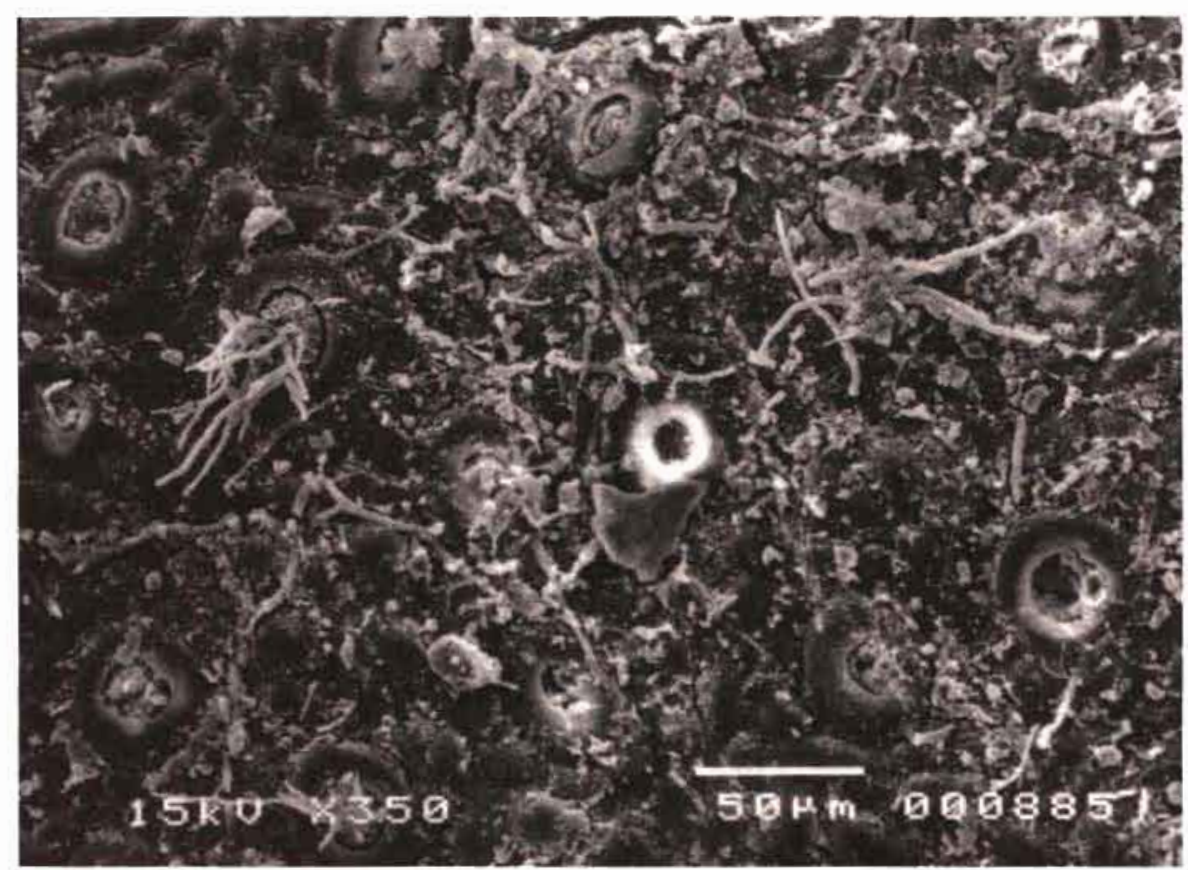

Fig. 4. Scanning electron micrograph of hyphae crossing stomata $(\times 525)$ of an eucalyptus leaf after 2 weeks immersion in a stream.

occurred mainly through stomata (Fig. 4). The oil vesicles of the eucalyptus leaves largely remain intact over time.

The addition of eucalyptus oils or tannic acid to the solid media completely inhibited or depressed fungal growth (Fig. 5). In fact, H. lugdunensis, L curvulo and $T$. angulatum growth was significantly decreased by the addition of either oils $(P<0.001$; $35.96 \leq F \leq 63.14)$ or tannic acid $(P<0.001: 33.77 \leq F \leq 243.49$ ) while the other fungal species (A. tetrocladia, L aquatico and T. gracile) did not grow at all.

Higher percentages of tannic acid were always needed to get a significative inhibition of fungal growth (Student-Newman-Keuls test: $P<0.05$ ) of fungal growth $-0.75 \%$ for $L$ curvula, $0.25 \%$ for $T$. angulatum and $H$. lugdunensis (vs. $0.1 \%$ oils in all

510 (ases). For the same concentration of tannic acid or oils, these species consistently exhibited smaller colonies in the presence of oils. Consistently, smaller amounts of oils were also needed to completely suppress growth of $H$. lugdunensis and $L$ curvula. In fact, low and similar values for EC50 were obtained when oils were present: 0.248 $(0.086-0.71795 \% \mathrm{CL})$ for $H$. lugdunensis, $0.290(0.186-0.4595 \% \mathrm{CL})$ for L curvula and $0.358(0.234-0.5595 \% \mathrm{CL})$ for T. angulatum. Lunulospora curvula was the most tolerant species to tannic acid ( $E C 50=2.202 ; 1.56-3.10495 \% \mathrm{CL}$ ) followed by $\mathrm{H}$. lugdunensis $(E C 50=1.1914 ; 0.83-4.4395 \% \mathrm{CL}$ ) and T. angulatum $(\mathrm{EC5} 0=0.528$ : $0.39-0.71595 \% \mathrm{CL})$. 

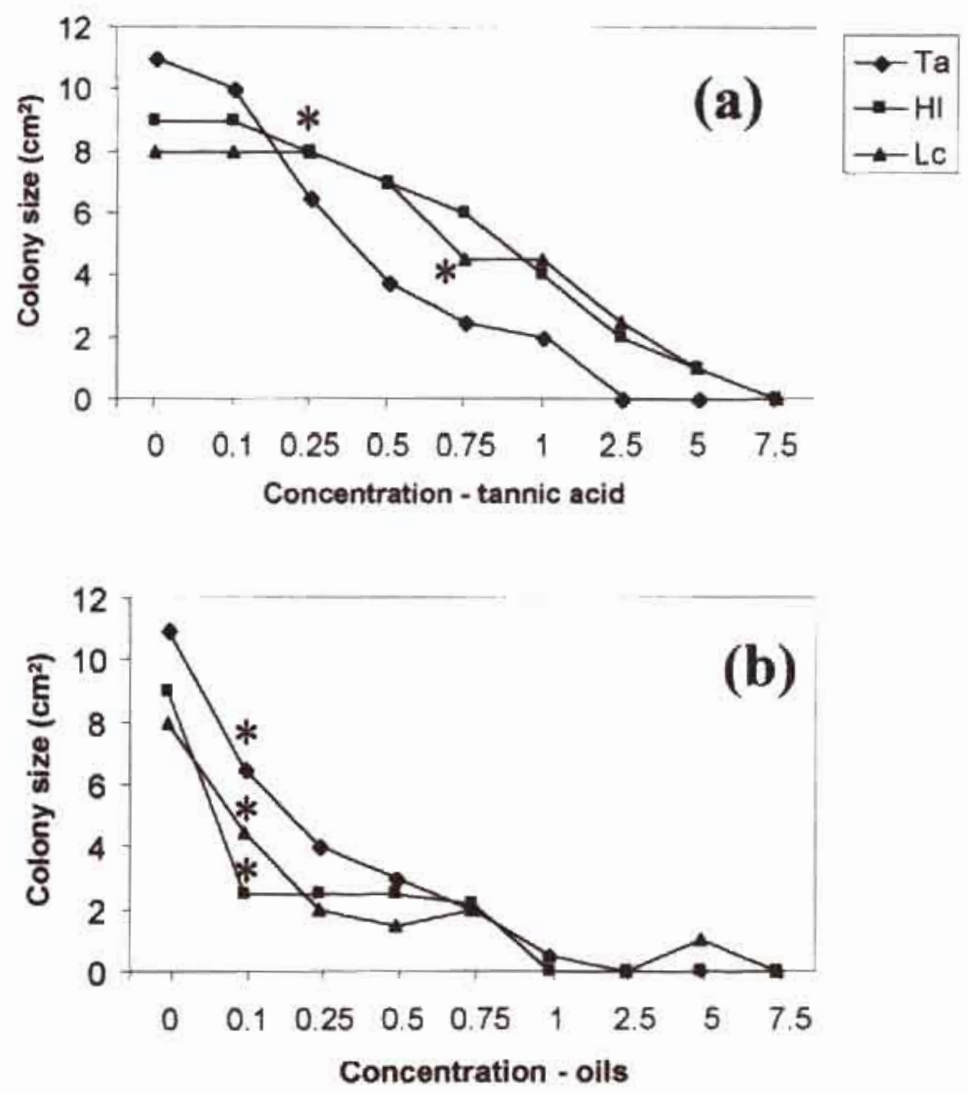

Fig. 5. Growth of 3 species of aquatic hyphomycetes in malt extract agar medium supplied with increasing concentrations of (a) tannic acid and (b) eucalyptus essential oils. Growth was allowed for 15 days. HI $=$ Heliscus lugdunensis; $\mathrm{Lc}=$ Lunulosora curvula: Ta $=$ Tncladium onguicutum. The symbol $*$ indicates the lowest concentration of tannic acid or oils that induced a significant $(P<0.05)$ decrease in fungal growth: (after Canhoto and Graça (999).

\section{Discussion}

Allochthonous organic matter plays a major role in energy and matter flow in low order streams. Abelho and Graça (1998) showed that perturbations of riparian areas as eucalyptus afforestations induced great changes in the patterns and quality of litter inputs to the streams. Originally dependent on autumn-shed leaf litter as the main energy source, many low order streams of Central Portugal rely now on a similar but continuous supply (with a peak in summer when discharge is minimal) of organic matter of low quality. 
Streams running through eucalyptus and deciduous forests differed in macroinvertebrate assemblages. These differences may be related with two main factors: first, a direct result of changes in the seasonality of litter inputs (Abelho and Graça 1996). Life-cycles with larval stages in autumn (when food was abundant) may be at higher risk of being eliminated by the eucalyptus new timing of food supply. Secondly, the leaves themselves may be a low quality resource. Previous papers (Canhoto and Graça 1992, 1995) demonstrated that Sericostomo vittatum (Rambur) and Tipula lateralis (Meig.), two common shredders in Portuguese streams, were unable to grow and survive in a diet of conditioned eucalyptus leaves. Leaf toughness, high phenolic and of contents (up to $5 \%$ of leaf weight; Costa 1964) have been considered responsible for the low food quality of these leaves (Mellilo et al. 1982. Campbell and Fuchshuber 1995, Canhoto and Graça 1995). A third factor may explain the differences in macroinvertebrate assemblages: changes in the streams hydrological regime. Abelho and Graça (1996) reported higher hydrophobic soils in eucalyptus forests. If this characteristic is a consequence of eucalyptus plantations, than rapid run-off in the rainy season prevents infiltration and therefore less water available in summer with a consequent drying of some small streams.

Eucalyptus leaves have some physico-chemical similarities with the deciduous oak and chestnut. Processed at a medium rate, as chestnut, the colonisation of the exotic leaves by aquatic hyphomycetes seems to be ruled by the particular presence of a resistant waxy cuticle that hardens the leaves and reduces hyphal penetrating capacity. A constrained (stomatal) area of fungal access to the leaf mesophyll is, most probably. the primary cause of the delayed, not decreased, conidia production observed in these leaves. Bärlocher et al. (1995) showed that, given enough time, maximal conidia production in fully conditioned eucalyptus leaves was higher than in alder; furthermore. the cumulative number of species is similar between both leaf species. Nevertheless, distinct patterns of fungal colonisation of eucalyptus from the other leaf species were detected (see Canhoto and Graça 1996) suggesting the possibility of a resource specificity of some fungi (Chamier and Dixon 1982).

The role of phenols and terpenes as defensive compounds against fungi is generally accepted (Bunn 1988. Bennett and Wallsgrove 1994. Bärlocher et al. 1995) and was corroborated by our study. As in marine and terrestrial environments (Steinberg 1988) oils showed a stronger depressing effect on fungal growth than phenols. Protected by the cuticle. the deterrent effects of both leaf defences in eucalyptus leaves seem to last for a long time: a slow initial decrease in polyphenolic leaf contents and an elongated integrity of the oil vesicles in the leaf matrix may inhibit fungal enzymatıc actıvity and limit microbıal colonisation (Canhoto and Graça 1999).

In summary, the microbiological breakdown of eucalyptus leaves, highly dominated by aquatic hyphomycetes, seem to proceed predominantly in and from the leaf mesophyll to the outside. primarily because of a resistant cuticle. The predominance of apparently intact but "hollow" leaves, common in eucalyptus streams, suggests that such degradation process may overlap shredders (low) consumption or density (see Canhoto and Graça 1999). 
In our experiments, mixed streams had an intermediate number of invertebrates. This is relevant for forest management since it seems to indicate that the presence of an unperturbed riparian corridor may attenuate the effects of eucalyptus plantations. A possible incorporation of eucalyptus litter into secondary production in a reasonable time span was also suggested by our work. However, differences in the timing of supply of eucalyptus detritus, distinct stream hydrology, potential changes in the stream fungal microflora and eucalyptus low quality to some shredders are crucial factors that must be carefully considered.

\section{References}

Abelho. M., and Graça, M.A.S. 1996. Effects of eucalyptus afforestation on leaf litter dynamics and macroinvertebrate community structure of streams in Central Portugal Hydrobiologra 324:195-204

Abelho, M. and Graça, MA.S. 1998. Litter in a first-order stream of a temperate deoduous forest (Margaraça Forest. central Portugal). Hydrobiologia 386 147.152.

Bärlocher, F, Canhoto, C, and Graça. M,AS. 1995, Fungal colonization of alder and eucalypt leaves in two streams of Central Portugal. Arch Hydrobiol, 133:457-470.

Bennett, RN. and Wallsgrove, RM. 1994 Tansley Review $N^{\circ} 72$. Secondary metabolites in plant defense mechanisms. New Phytol, 127:617-633.

Bunn. S.E. 1988. Processing of leaf litter in two northem jarrah forest streams, Western Australia. II. The role of macroinvertebrates and the influence of soluble polyphenols and inorganic sediment. Hydrobiologio $162: 211-223$

Campbell, I.C. and Fuchshuber, L. 1995. Polyphenols, condensed tannins, and processing rates of tropical and temperate leaves in an Australian stream. 1. N. Am. Benthol. Soc. 14: 174.182.

Canhoto, C., and Graça, M.A.S. 1992. Importância das folhas de eucalipto na alimentaçăo de detritivoros aquáticos em nbeiros da zona centro de Portugal. Actas do V Congresso lbérico de Entomologia I: 473 . 482

Canhoto. C. and Graça. MA.5. 1995. Food value of introduced eucalypt leaves for a Mediterranean stream detritivore:Tipula lateralis. Frestiwot. Biol. 34: 209-214.

Canhoto. C. and Graça. M.A.S. 1996. Decomposition of Eucalypturs globulus leaves and three native leaf species (Alnus glutinosa, Castanea sativa and Quercus faginea) in a Portuguese fow order stream. Hydrobiologio 333: 79-85.

Canhoto, C.. and Graç, M.A.S. 1999. Leaf barriers to fungal colonization and stredders (Tipula lateralis) consumption of decomposing Eucalyptus globulus. Microbiol. Ecol. 37: 163-172.

Chamier. A.C., and Dixon, PA. 1982. Pectinases in leaf degradation by aquatic hyphomycetes: the enzymes and leaf maceration.). Gen. Microbul. 128: 2469-2483.

Costa, A.F. 1964. Eucalipto. In Farmaçagnosia Vol I. Edited by Fundaçào Calouste Gulbenkian, pp. 472 -478. Farmacopera Portuguesa 1986. Oficine (ed). Imprensa Nacional, Casa da Moeda, Lisboa.

Finney, D.J 1971 Probrt analysis. Cambondge University Press, Cambnige.

Martin, 1.S. and Martin. MM. 1982. Tannin assay in ecological studies: lack of correlation between phenolics, proanthocyanidins and protein preciprtating constivents in mature foliage of six oak species. Oecologia 54: 205-211.

Molles. M.C. 1982. Trichopteran communities of stream associdted with aspen and conffer forests: long-term structural change. Ecology $63: 1.6$

Mellilo. J.M., Aber. J.D., and Mauratore, J.F. 1982 Nitrogen and ignin control of hardwood leaf litter decomposition dynamics. Ecology 63:621-626.

Petersen, R.C., and Cummins, K.W. 1974. Leaf pack processing in a wordland stream. Freshwat Brol. 4.343368.

Spurr.A.R. 1969. A low viscosity epoxy resin embedding medium for electron microscopy. J Ult Res 26:31. 43.

Stemberg, P.D. 1988. Effects of quantitative and qualitative variaton in phenolic compounds on feeding in three species of marine invertebrate herbivores.j. exp. Mar. Biol. Ecol, 120:221-237. 
Stout III, B.M. Benfield. E.F. and Webster. J.R. 1993. Effects of a forest disturbance on shredder production in a southern Appalachian headwater stream. Freshwat Biol, 29:59-69.

Wallace, J.B., Eggert. S.L. Meyer. J.L. and Webster. J.R 1999. Effects of resource limitation on detrital-based ecosystem. Ecol. Monogr 69: 409-444.

Wilde, S.A. Vorgst. G.K. and lyer, J. G. 1972 . Soil and plant analysis for tree culture, Oxford and IBH Publishing Company. New Delhı, India.

Zar, J.H. 1984. Biostatistical analysis. Prentice-Hall, Englewood Cliffs, New Jersey, 

Série

Investigação

$\bullet$

Coimbra

Imprensa da Universidade

2002 